\title{
Mothers and Parents' Marital Relations: Influential Agents in Father-Child Relations
}

\author{
Hilal Çelik ${ }^{1, *}$ \\ ${ }^{1}$ Department of Psychological Counseling and Guidance, Marmara University, Turkey \\ *Correspondence: Marmara University, Göztepe Kampüsü, Atatürk Eğitim Fakültesi, Eğitim Bilimleri Bölümü, \\ 34722 Kadıköy, Istanbul, Turkey. Tel: 90-505-372-5124. E-mail: hilalcelik@marmara.edu.tr, celikhilal@gmail.com
}

Received: January 9, 2020

Accepted: February 10, 2020 Online Published: February 20, 2020

doi:10.5430/wje.v10n1p164

URL: https://doi.org/10.5430/wje.v10n1p164

\begin{abstract}
This study examines how parents' marital relations and the explicit and implicit messages conveyed by mothers to their children about their fathers affect father-child relationships. A homogeneous sampling method was used to select as the participants nine women and seven men, aged 18-20 ( $\mathrm{x}=18.88)$, all of whom were students in the Departments of Turkish Language $(\mathrm{N}=6)$, Mathematics $(\mathrm{N}=5)$, and Psychological Counseling at Marmara University in Istanbul, Turkey. The data were collected using the semi-structured, in-depth interviewing technique and were analyzed using Interpretative Phenomenology Analysis. This study identified three overarching themes as part of the analysis: (i) children's varying interpersonal boundary relationships with their parents, (ii) relationship issues in the parents' marriage which affect the father-child relationship, and (iii) inconsistency in the messages conveyed by mothers regarding the fathers. The findings are explained within the contexts of Turkish culture, family therapies, and the extent literature on fatherhood.
\end{abstract}

Keywords: father-child relationship, mother-child relationship, parents' marital relations, influence of the mother, Turkish families

\section{Research Background}

The phenomenon of fatherhood, which became a focus for Western researchers in the 1980s, has recently begun to attract the attention of researchers in Turkey. Research findings indicating positive contributions of fathers in the lives of their children accelerated this Turkish area study. Many research studies report that fathers contribute positively to the social (Stolz, Barber, \& Olsen, 2005), academic/cognitive (Flouri \& Buchanan, 2004; Howard, Lefever, Borkowski, \& Whitman, 2006), personality and sex role (Howard, Lefever, Borkowski, \& Whitman, 2006), and emotional (Dubowitz et al., 2001; Flouri, 2005; Formoso, Gonzales, Barrera, \& Dumka, 2007; Schwartz $\&$ Finley, 2006) developments of their children.

Theorizers emphasize that father hood is a multi-dimensional phenomenon, derived from a combination of many variables rather than merely a one-to-one relationship between a male adult and a child (Lamb, 2000; Lamb \& Oppenheim, 1989). Variables such as the psychological characteristics of the father (Grossmon, Pollack, \& Golding, 1988; Levy-Shiff \& Israelashvilli, 1988), the psychological characteristics of the child (Lamb, 2000; Krampe, 2009), the education levels of the parents (Coltrane,1995; Pleck, 2010), the employment statuses of the father and the mother (Coltrane, 1995; Thomas and Hildingsson, 2009), the income level of the father (Amato \& Booth, 1997), the working hours of the father (Crouter, Bumpas, Head \& McHale, 2001; Milkie \& Peltola, 1999), the child's age (Lamb, 2002), the child's gender (Coley \& Morris, 2002), the state of the parents' marital relations (Cummings, Goeke-Morey, \& Raymond, 2004; Rane \& McBride, 2000; Orbuch, Thornton \& Cancio, 2000), the mother's role in the family (Krampe, 2009, Krampe \& Newton, 2006; Puhlman \& Pasley, 2013), the parents' relationships with their own fathers, and their cultural beliefs (Lamb, 2010; Krampe \& Newton, 2006) are all factors that shape fatherhood.

A definition of how fatherhood is experienced culturally is required in order to understand both the way fatherhood is shaped and experienced in Turkey and the contributions of fathers to the lives of their children. Deductions regarding fatherhood can be obtained by examining both the developmental results of their children and the extent to which the conduct of fathers overlaps with cultural and broader familial directives and desires regarding children 
(Amoto, 1998; Lamb, 2010). Suggesting that an independent definition of fatherhood is not possible, Lamb (2010) reported that basic standards and definitions of parenthood (and thus fatherhood) cannot be established independently from culture. Variables such as culture, ethnic origins, socio-economic status, and geographical region shape the roles of women and men in accordance with localized criteria (Amoto, 1998; Cabrera, Fitzgerald, Bradley \& Roggman, 2007; Krampe, 2009; Morman \& Floyd, 2006).

Cultural context delivers different implicit and explicit messages to mothers and fathers regarding their parental roles. The parents' marital relationship and their family roles are often influenced by societal traditions and expected gender roles for men and women. And like motherhood, fatherhood is also shaped by the dynamics of domestic relations (Krampe \& Newton, 2006; Saracho \& Spodek, 2008). Therefore, theorizers suggest that evaluating father-child relationships dyadically (father-child) would lead to un-useful results; these relationships instead should be evaluated both triadically (mother-father-child) and systematically. Under typical conditions, it is the mother that introduces the father to the child within the family system; that helps to bring the father into the child's symbolic world. For the mother to be able to do that, she should give a role to the father in her own symbolic world, and the father should assume this role (Parman, 2004).

Recent research findings suggest that mothers occupy either a facilitating or inhibiting role in the father-child relationship (Allen \& Hawkins, 1999; Puhlman \& Pasley, 2013). Mothers can open or close the doors of the family to fathers by relying, or not, on the parental sufficiency of the father (Makusha \& Richter, 2016; Schoppe-Sullivan, Brown, Cannon, Mangelsdorf, \& Sokolowski, 2008; Trinder, 2008; Tu, Chang \& Kao, 2014). Mothers also convey implicit and explicit messages to their children regarding how they should perceive their father as an individual and what to think about him. These messages enliven or erode the child's first affectionate bond with and mental representation of the father in the early period. If the mother has positive feelings towards the father and encourages the child to approach the father through her messages, and if the father and child respond to these and interact with each other, a strong bond is created between the father and the child. On the other hand, if the mother looks down on the father, dislikes him, keeps an emotional distance from him, and sends negative messages about him, the child may withdraw from or even fear the father (Krampe, 2009). In this respect, the role of mothers in creating a family atmosphere and keeping domestic peace and balance allows them to shape, or not, a positive image of the father in the eyes of the children (Seery \& Crowley, 2000).

Marital relations is another variable that affects fathers in their attempts to assume a fatherhood role and to determine the quality of their relationship with their children. According to Cowan and Cowan (2000), the relationship between a husband and wife significantly affects their parenting duties. When evaluated systematically, the father's involvement is closely related to marital interaction (Krampe \& Fairweather, 1993), and good marital relations (Cummings et al., 2004) are correlated with more active roles of fathers in childcare. Compared to mothers, fathers are much more affected by the husband and wife relationship. If the marital bond is weak, they may isolate themselves more, and this may reduce their parenting performance and weaken the father-child relationship. Having good marital relations, based on intimacy and trust between the spouses, helps the man to perceive himself as a sufficient father. Researchers often report that men who are engaged in a romantic and emotionally intimate marriage show more fatherly involvement and establish more emotional intimacy with their children (Bouchard \& Len, 2000; Rane \& McBride, 2000; Orbuch et al., 2000).

Marital relations and the mothers' role are among the more important variables to be considered in the study of fatherhood in Turkey. Today in Turkey, it is true that fathers' distance from their children due to power relations has been reduced, while respect and the children's attention to their father have been maintained; emotional closeness between parents and children is said to be typically high (Kağıtçıbaşı, 2010; Sunar \& Fişek 2005). However, Fişek (2018) indicated that this emotional closeness applies mostly to the mother-child relationship, wherein there is a strong, shared sense of togetherness/mutuality, intense emotional exchanges, love, support, loyalty, and general closeness between mothers and children. A mother's inner being is said to exist within the child's ego. But for fathers, there is more dissociation, which derives from the family hierarchy between father and child. For Turkish adolescents, who create a relatively close and intimate bond with their mothers and a more distant bond with their fathers, messages conveyed by mothers regarding their father and their perceptions about their parents' marital relationship are important criteria when they evaluate fatherhood. Thus, this study aims to (1) define the common perceptions of adolescents in families of the middle socio-economical level regarding their father-child and mother-child relationships, (2) examine how they perceive the messages conveyed by their mothers regarding their fathers, (3) identify the childrens' shared perceptions of their parents in relation to their parents' marital relationship, and (4) determine how all these factors influence their father-child relationship. 


\section{Methodology}

\subsection{Research Design}

We used Interpretative Phenomenological Analysis (IPA) to identify shared participant experiences regarding the the influence of messages conveyed by mothers about fathers and their perception of the significance of their parents' marital relations in their father-child relationships (Smith \& Osborn, 2003). IPA was selected because it helps to describe the phenomenon experienced by the participants, and it allows both the participants and the researchers to interpret implicit meanings (Creswell, 2009). The researcher conducted the analysis by comparing the participants' explanations, the content of the data, and her own framework for interpreting meaning.

\subsection{Setting and Recruitment}

The study was conducted with permission from the Head of the Educational Sciences Department of Marmara University from June-November 2019. The sampling followed this criteria: the participants should (i) have biological parents, (ii) have been raised by them, (iii) have lived with these parents during childhood or still be living with them, (iv) have married parents, (v) have parents who did not have a prearranged marriage, (vi) have a family with medium SES, and (vii) be a freshman. The fifth criterion was included to minimize potentially low emotional intimacy between parents due to separation. The sixth criterion was included because continuity or changes in family dynamics in Turkey are mostly observed in families with this level of SES. The reason for including the seventh criterion was to minimize the potential effects of university education on the participants' observations about family dynamics. The researcher informed the students about the content of the study during her lectures. The study was conducted with 16 voluntary participants, who were homogenous in terms of their demographic features.

\subsection{Sampling and Participants}

Table 1. Sample Demographics ( $\mathrm{N}=16)$

\begin{tabular}{|c|c|}
\hline Variables & $\mathrm{N}$ \\
\hline \multicolumn{2}{|c|}{ Mothers' Employment status at the time of the study } \\
\hline Unemployed/Housewife & 6 \\
\hline Employee & 6 \\
\hline Working at her husband's workplace for free & 4 \\
\hline \multicolumn{2}{|c|}{ Fathers' Employment status at the time of the study } \\
\hline Unemployed & - \\
\hline Employee & 16 \\
\hline \multicolumn{2}{|l|}{ Mothers' Education } \\
\hline Undergraduate & 2 \\
\hline High school & 7 \\
\hline Middle school & 6 \\
\hline Elementary school & 1 \\
\hline \multicolumn{2}{|l|}{ Fathers' Education } \\
\hline Undergraduate & 6 \\
\hline High school & 9 \\
\hline Middle school & 1 \\
\hline Elementary school & - \\
\hline \multicolumn{2}{|l|}{ Number of siblings } \\
\hline One & 4 \\
\hline Two & 6 \\
\hline Three or more siblings & 6 \\
\hline \multicolumn{2}{|l|}{ The place where family members live } \\
\hline City & 10 \\
\hline Town & 5 \\
\hline Village (rural area) & 1 \\
\hline \multicolumn{2}{|l|}{ Family structure } \\
\hline Extended & - \\
\hline Nuclear & 12 \\
\hline Living with extended family for a while & 4 \\
\hline
\end{tabular}


The researcher preferred a homogenous sampling method to focus on a certain experience within a particular context and period of time. This facilitates the examination of similarities and differences between the experiences of the participants in a detailed manner. Nine women and seven men participated; all were aged 18-20 ( $\mathrm{x}=18.88)$ and were students in the Departments of Turkish Language $(\mathrm{N}=6)$, Mathematics $(\mathrm{N}=5)$, and Psychological Counseling at Marmara University. The demographic variables of the participants in the sample are illustrated in Table 1.

\subsection{Interviews}

In-depth interviews of the participants were conducted by means of a demographic survey and semi-structured interviewing questions. Audio recordings of the interviews, which lasted from 47-93 minutes, were kept with the consent of all the participants. The researcher asked the participants different types of questions: (i) grand tour questions: to address the phenomenon or cultural context, and (ii) follow-up questions: to ask for further details about an act, event, or category.

\subsection{Data Analysis and Interpretation}

The researcher followed the data analysis steps of Smith and Osburn (2003), transcribing all the data verbatim and using MaxQDA-11 software. During the data analysis process, the researcher first focused on how the implicit and explicit experiences, feelings, and perceptions of the participants were shaped, and interpreted and listened to the audio recordings several times. At this stage, the researcher also read the texts multiple times without any coding and thus became familiarized. Additionally, the researcher wrote memos regarding what the participants said, how they said it, how they used the language, and the context. Afterwards, she took descriptive notes (basic meanings of what was said), linguistic notes (pauses, intonation, stresses, etc.), and conceptual exploratory (comments and reflections) notes. This process helped the researcher to define developing themes. Then, the researcher established connections between the developing themes and grouped the themes according to conceptual similarities. In the last stage of the analysis, the researcher supported the analytic interpretations she had made with narrative examples from the participants' statements and defined each theme.

\subsection{Trustworthiness}

The researcher ensured the trustworthiness of the study using a variety of strategies. First, significant attention was paid to the data collection, analysis, and interpretation processes. The interviews were transcribed verbatim by the researcher with a sincere effort to accurately reflect the audio recordings. To enhance credibility and conformability, the researcher employed reflexive memoing to document her personal reflections on the research process and used these memos as an analysis unit. She included teleological examples and quotes from the participants (thick description) to ensure transferability. And finally, she took consent about whether the themes she developed reflected the actual experiences of the participants by contacting two female and two male participants via e-mail (member checking) (Lincoln \& Guba, 1985).

\subsection{Researcher's Role}

Playing an active role in the study, the researcher employed an empathetic approach to reflect the perceptions of people experiencing the phenomenon with the viewpoint of an insider, and used a questioning stance as an outsider/stranger to examine the phenomenon from different angles. The fact that she was raised in a middle-class family and with her parents in Turkey facilitated the researcher's empathetical attitude, while the facts that she is a member of a couple, a family therapist, and had conducted clinical and academical studies on father-child and family relationships helped her employ a questioning and analytical stance. Throughout the study, the researcher focused on the perceptions of the participants regarding themselves and their experiences, on meanings attributed to the interview narratives, and how to interpret these.

\section{Findings}

Three overarching themes emerged during this study: (1) children's varying interpersonal boundary relationships with their parents, (2) relationship issues in the parents' marriage, and (3) inconsistency in the messages conveyed by mothers regarding the fathers. While each young individual's experiences were unique, they were related to the experiences of the other young individuals who had similar experiences.

\subsection{Varying Interpersonal Boundary Relationships with the Parents}

All the participants offered statements which suggested that their interpersonal boundaries between mother-child and father-child relationships were somewhat different. In sum, however, their narratives indicated that the father-child relationship was generally (i) rigid and characterized by emotional distance; and (ii) that the 
mother-child relationship was generally enmeshed and characterized by deep emotional sharing.

\subsubsection{The Rigid Father-child Relationship}

A distant father-child relationship which does not include emotional closeness to the desired extent was one of the most saturated themes experienced by the participants. They clearly noted that this distance was connected to the hierarchy of generations. An 18-year-old participant, who was raised in a big city and whose parents are working, said this: "He is a father, after all. You can't be the same with your father as you are with your mother. One can talk to her mother about everything, but it is different when it comes to the father... So that you don 't get too intimate... $\mathrm{He}$ is a father, and there is a severity in this. He expects respect from everyone. You cannot yell at him or tell everything to him, like you do with your mother. You talk to him only when it is necessary."

The participants indicated that the hierarchy of generations influences the father to be: (i) authoritative, (ii) emotionally inexpressive, and (iii) insufficient regarding parenting attitudes.

Authoritativeness: Seven participants explicitly described their fathers as authoritarian, while nine did so implicitly. One of the participants offered this explicit comment: "We can't get along with my father. We are just the opposite of each other... I am keen on my freedom, and I am an adventure-seeker, while my father is an authoritarian, obstinate man with an attitude of I know everything." The participants who offered implicit descriptions indicated that their fathers were authoritarian by linking them to these characteristics: (i) being relatively closed to communication, (ii) being disciplined, strict, and short-tempered, (iii) possessing low tolerance for criticism, (iv) giving family members limited rights to speak, (v) possessing a tendency to arrange important family decisions according to his own expectations, and (vi) expecting respect in all kinds of situations. A female participant said: "... Whatever you do, your mother can't spare you as her child; [so] she listens to you, whatever happens. But even if the father doesn't say it aloud, he has the attitude of 'I am the head of the family'... Maybe even after twenty years, when I turn 40, he will always say 'What did you see in your life, what do you know?"” Another participant's comment on this theme was: "When we say something, he laughs at it if he is in a good mood. But if I say the same thing normally, he will say 'How dare you talk like this with your father'... Once, he learned that I smoked, but he didn't come to talk to me. He told my mom, Tell her to quit'... If I talked to him, he would generally say, That's how we experienced it. You can't teach anything to me at this age.",

Emotional inexpressiveness: All the participants provided statements about how they could not establish a desired emotional closeness with their fathers, and that this is problematic for them. A majority of the participants (12) stated that they became emotionally more distant from their fathers after a certain age, when the frequency of their emotional interactions through verbal and physical contacts (kissing, hugging, patting on the back, etc.) decreased. All the participants stated that they had problems feeling that they were loved by their fathers, though they knew it at an intellectual level. One participant said: "We know that our father loves us, but he is a typical father; he doesn't show it. I think my father is an avoider. He does everything we want, but he doesn't give the love he is supposed to give, and we grow up in this way." A male participant, who had physical interactions with his father during his childhood but expressed that he started to sense his father's love only indirectly after his adolescence, said: "Hugging and kissing were over after my childhood. We are at a different level now... He loves us, but he is one of those guys who don't show it. He becomes sad when I get sick... and he didn't eat anything when I couldn't pass the exam for university. I get it in a way."

Insufficient parenting attitudes: The participants indicated that both the inferior position of the fathers compared to their mothers during their childhood and mother-focused childcare damaged their relational bond with their fathers. While all the participants found it normal that mothers assume an active role in childcare, since they were women, they explained the inferior position of their fathers as due to his indifference. Fourteen participants reflected on the connection between indifference and their father's emotional distance in their father-child relationship. One participant said: 'My father's basic mission is maintaining the family, of course. He shouldn't let our family be poor... No one has ever expected him to do chores or cook, so far. This is against his nature anyway. He could visit my school, follow my lessons... but I don't remember that he has ever come and showed interest. He is indifferent. He usually learns things about me through my mother. I have never seen a child who cried 'father' when he falls. Children always call their mom; fathers are more like a shadow. One tends to turn towards whomever understands him; that is the mother."

\subsubsection{Enmeshed within the Mother-child Relationship}

All the participants defined motherhood in connection with the themes of love and deeply affectionate ties. They indicated that the factors which define motherhood include a mothers' actions: (i) taking the primary role in 
childcare, (ii) housekeeping, (iii) ensuring peace and a relational balance at home, (iv) being compassionate, (v) being unconditionally accepting and understanding, and (vi) using affectionate forms of communication. For example: "My mother is the backbone of the family. If it wasn't for her, our family would collapse because she is the one who manages everything. If something happens to any of us, my mother will call and gather everyone. I will call my mother instead of my father if something happens to me. My mother establishes the bond between us. She knows everything; she is very understanding and very self-giving; and she doesn't think of herself. She makes an effort to keep her family in a good way. She doesn't have a private life and never says she has another plan. She always makes her plans according to us."

All the participants suggested that their family definitions are focused on the mother. These reflections were closely connected to their perceptions that (i) the mother devotes her life to her children more than the father, (ii) the father is passive in housekeeping and childcare, and (iii) the father has an individual life which is separate from his family life. As a clear example to this, one of the male participants said: "Family means mother... I wish I had a similar closeness with my father... My father thinks he expresses many things, but it is not enough for me. My mother devoted herself to us. I can't help but compare them. I find my father insufficient." And one of the female participants said: "My father should be devoted to his family first. He has a life that he created with his wife and two children. He should think he must make time for them and arrange his life according to them. But he tries to live his life more individually."

The participants indicated that their mother-child relationship was defined by closeness, including intense emotional ties. Also, there was an issue of affective separation between mother and child. Eleven participants stated that their fathers had an individual and isolated life within the family, while their mothers devoted their lives to their children. Thus, they had established a closer and deeper relationship with their mothers. For example: "Sometimes I think, what if they die, and I start to cry. I can't deal with her death; I can't be myself without her... I would be very sad over my father's passing too, but it is different with my mother. I am thinking that my mother is living only for us. My father is also living for us but in a different way... My mother has been working in the fields since she was 17. She took care of both us and our home... I can never make it up to her. I feel connected to my mother and siblings in a very different way. Like I said, I sometimes can't see my father as part of our family because he is not involved in the concept of family that much."

\subsection{Relationship Issues in the Parents' Marriage}

Many participants indicated that their parents' marital relations presented problems. The question, "What can you say about your parents' marriage? What kind of relationship do you think they have?" was answered by 14 participants. The responses were (i) problematic, (ii) standard/typical, and (iii) neutral, and (iv) two of the participants' answers were "good." One who defined the parental marriage as problematic said: "They don 't have affection; I don't think they have a romantic relationship. Well, they have been married for 20-25 years. I don't know if love dies in time, but it is not the marriage I have been dreaming of. What is between them is reflected on us, as well."

The participants who defined their parents' marriage as good said that this is closely connected to the efforts of their mothers. For example: "The best thing my mother does is to go easy on my father. They are on good terms with each other... They can get along well because my mother can meet halfway and go easy on my father. They sometimes argue, but usually the argument ends thanks to my mother... My mother sometimes calls my father 'dear'. She is the one who gets along easily. If my mother was different, their relationship would be more challenging."

The participants' answers for the question: "What kind of relationship do you think your parents have? How is their relationship reflected in your relationship with your father?" were grouped under two sub-themes: (i) instrumental/structural relationship or (ii) expressive relationship.

\subsubsection{Instrumental/Structural Relationship}

All the participants stated that the relationship between their parents was based upon meeting the needs of the house and children in general, and that this relationship conformed to the gender hierarchy. While the participants found it normal that mothers assumed more roles in the family compared to fathers, they also evaluated this situation as unbalanced, unequal, and unjust (for the mother). The participants indicated that this imbalance was reflected in their father-child relationships and had led to their tendency to blame their father for troubled and unhappy moments in the family while excusing their mother in every situation. One of the male participants, whose parents were both working, said: "My mother comes home and has to do everything, like cooking and washing the dishes. My father is like the king. He lies on the sofa and watches TV for hours. They both work a lot. One should 
think that this woman is also working and tired. My father can't even break eggs. When something happens, he says, 'What do you say? Didn't I help you when you asked for it?' My mother is exhausted. I seriously want to hit my father on the mouth sometimes."

\subsubsection{Expressive Relationship}

The participants had a shared perception about their parents being able to express their negative emotions to each other both verbally and nonverbally in an open way (getting angry, yelling, insulting, blaming, swearing, etc.), while not showing or rarely showing (generally only by mothers towards fathers) their positive affections (kissing, hugging, showing affection, saying positive things, etc.). Fourteen participants discussed seeing their mothers as the victim and the justified party, while blaming and seeing their fathers as the guilty one, in general, when their parents expressed negative emotions to each other. They also stated that this situation reflected negatively on their father-child relationship. One participant, who mentioned that his parents had a loving marriage, said: "I have never seen that they hugged or kissed each other around us. They congratulate each other's bairam and kiss at those times, but I haven't witnessed it at other times. I have never heard them using words like my love, dear, etc. They probably love each other... [But] My father becomes a disgusting person when they argue, and he swears a lot. I don't know how he can look at her face after swearing like that. My mother can also be wrong sometimes, but she never swears... As a matter of fact, I can't put up with a person who upsets my mother, even if that person is my father."

\subsection{Inconsistent Messages from the Mother about the Father}

The participants' said that the messages conveyed by their mothers about their fathers were characterized by their inconsistency. All the participants said that they had received both positive and negative messages from their mothers about their fathers, explicitly and implicitly, and that this could be one of the factor led to develop negative feelings about their fathers. Eleven participants stated that they had received positive messages from their mothers about their fathers, including that he was (i) self-sacrificing, (ii) hardworking, (iii) nice, and (iv) faithful (=doing everything to meet the material needs of their children). But they also gave clear examples of receiving at the same time negative messages about the insufficiency of their fathers' parenting. For example: "My mother tells me that my father is self-sacrificing. She says, 'He is really very responsible and tries to do everything we say'... She actually likes him as a father," said one participant, who then added: "My mother says: 'Even if he doesn't have a coin in his pocket, he finds one and sends his children to school; he does everything. But he is disinterested. He doesn't' show his love to his children, and he is distant'. My father meets my needs, I must give him his due. But he is cold and doesn't show his feelings."

Twelve participants revealed that they did not differentiate between the concepts of "being a husband" and "being a father," and they conflated these two concepts when explaining the phenomenon of fatherhood from the perspective of their mothers. They indicated a relationship between negative evaluations from their mothers about their husbands and the participants' negative feelings towards their fathers. One participant said about this link: "My mother says, 'give your father his due, do this, do that, he loves you'. But for example, she holds my father responsible for problems with my grandmother when my father is at work or having breakfast. So, I think sometimes she imposes too many ideas on me about him... Even when a simple problem occurs, my mother always says to my father, you did this and this happened because of you' and I tend to think this happened because my father did so, meaning my father is the guilty one,' and I feel estranged from him. " Another participant, who claimed to be like friends with his/her mother and that they shared secrets with each other, said: "It is very tough to hear what my father did in the past. My mother tells me from time to time, and sometimes lets it slip when she argues with my father. I think it is offensive and disgusting when a man behaves like sex is the only thing that he wants from his wife. I don't like it. That's why I hated my father for a while. It is sometimes good to be distant from him."

The participants also offered examples of their mothers conveying messages which led to the participants feeling guilty. Nine participants gave examples of receiving messages from their mothers which suggested that the parents had children as a reason for continuing an unhappy marriage, and that they make sacrifices because they want their children to be raised in a family environment. For example: "My mother usually says, If you study, I can live on my pension... I am putting up with your father for you'... I am getting upset; my mother is getting exhausted because of work, us, and my father. She often cries when she is with me... I think it is impossible for me not to be affected when my father upsets my mother. Eventually, my mother does everything for us. Maybe because of this, I want to get a job immediately." 


\section{Discussion}

The study findings reveal several important points for professionals and theorizers who design family counseling training and conduct counseling services. Firstly, the participants identified a rigid boundary relationship between father-child and an enmeshed boundary relationship between mother-child. They suggested that the rigid relationship between father-child relates to the generational hierarchy, and they associated this with authoritativeness, emotional inexpressiveness, and insufficient parenting attitudes of their fathers. The participants also stated that they had a different kind of bond with their mothers. They associated that bond with the behaviors of their mothers, which include her provision of unconditional love, affectionate communication, self-devotion, and peace-keeping and balance in the family, in every situation and for the sake of the children. The participants' statements reflected that this bonding with parents related to their affective separation problems, as well.

This findings of this study are congruent with other recent research findings in Turkey and agree with the basic assumptions of family theorizers (Ataca, 2009; Boratav, Fişek, \& Ziya, 2014, 2017; Çelik, 2019; Sunar, 2005). Underlining that child-parent relationships in Turkish families are multi-dimensional, Fişek (2018) reported that there is typically very strong and intense emotional exchange and enmeshment between mother and child, while there is a distance derived from the structural hierarchy between father and child. In the Turkish family model, where relational self is cared for and commitment and loyalty to the family are essential (Kağıtçıbaş1, 2010), and children are not encouraged to separate from the family to develop an autonomous self (Fişek, 2018).

Recent research studies report that the dynamics of father-child relationships have changed (Floyd \& Morman, 2005; Boratav et al., 2017; Morman \& Floyd, 2006; Sunar, 2002), but fathers in Turkey still remain distant from their children and communicate less (maintaining a more distant relationship tends to limit communication), compared to the mothers, in order to avoid spoiling the children or allowing them to be disrespectful (Ataca, Kağıtçıbaşı \& Diri, 2007; Boratav et al., 2014; Barutçu \& Hıdır, 2016; Sunar, 2009; Çelik \& Bulut, 2019). Research findings also show that these qualities of fatherhood are associated with traditional/authoritarian behavior, and that they influence father- child relationships in a negative way (Bulanda, 2004; Gaertner, Spinrad, Eisenberg \& Greving, 2007; Paquette, Bolte, Turcotte, Dubeau \& Bouchard, 2000). The relationship between mother and child is generally more affectionate; mothers spend more time with their children, assume more responsibilities about everything regarding their children, and establish closer relationships with them (Anne Çocuk Eğitim Vakfı [AÇEV]; Ataca, 2009; Bozok, 2018; Jacobs \& Kelley, 2006). Boratav et al. (2017) and Çelik (2019) stated that the relationship between father and child is perceived as a kind of relational wound, which creates a feeling of deprivation in children. In terms of Bowen family system theory, this situation can compromise the development of an autonomous self in children. There is a risk for an individual who cannot establish optimal closeness with even one of the child's parents, as that is needed to create emotional bonding which is essential for healthy development.

The second important result relates to the participants' statements about problematic emotional bonding in the father-child relationship due to their perceptions of their parents' relationship issues. The participants stated that their relationships with their parents were shaped by gender hierarchy and were focused on housekeeping and childcare. They evaluated the relationship between their parents as imbalanced in these areas, which led to their perception of the workload being unjust and unequal for the mother. Moreover, they associated this imbalance with negative feelings they had developed towards their father. They expressed their tendency to see their father as guilty and their mother as justified when she complained, and they believed that she was a victim during moments of uneasiness and unhappiness in the family. Our findings also show that these participants' had strong perceptions that their parents are incapable of being positively expressive towards each other and that they have a problematic relationship. These perceptions are associated with their observations of their parents expressing their negative emotions to each other both verbally and nonverbally in an open way (getting angry, yelling, insulting, blaming, swearing, etc.) while not showing or only rarely showing (generally by mothers towards fathers) positive affections (kissing, hugging, showing affection, saying positive things, etc.). The study findings therefore indicate that a negative relationship between the parents is related to children's negative feelings towards their father.

This finding can be explained by references to culture and concepts of family therapies. Researchers report that even today, mothers are at the center of family relations in many cultures, and fathers hold a more inferior/subordinate position in household chores and childcare (Boratav et al., 2017; Hu 2011; Paquette \& Bigras, 2010; Vogel, Bradley, Raikes, Boliler, \& Shears, 2011). The roles of men and women, thus mothers and fathers, are not equal, even if gender hierarchy has decreased in modern families in Turkey; mothers still occupy a role of being more expressive and caring for the child, while the fathers continue to support the family financially (AÇEV, 2017; Bozok, 2018; Kağıtçıbaşı, 2010). In this family model, children also have more chances to observe the 
parenting practices of their parents and less chances to observe their husband-wife relationship. In Turkish families, Islamic values prevail; in this culture, it is usually regarded as "disgraceful" for parents to show positive affections towards each other (kissing, hugging, showing intimacy, etc.) around their children, while it is typical for them to conflict or argue in front of them (Kağıtçıbaşı, 2010; Sunar, 2002, 2009). This decreases the possibility for children to witness the positive affections of their parents towards each other, while it increases the possibility for them to witness their negative emotions. However, good marital relations, including the showing of positive feelings between the parents, is one of the determining factors for a good father-child relationship (Krampe \& Newton, 2006, Krampe, 2009; Orbuch et al., 2000). Cowan and Cowan (2000) report that a satisfying romantic relationship between husband and wife facilitates the parenting duties of fathers. Researchers report that satisfying marriages with affection, intimacy, trust, and romanticism lead to a higher level of father involvement in parenting, while unsatisfying marriages with conflicts, tension, and distance lead to a lower level of father involvement (AÇEV, 2017; Bouchard \& Lee, 2000; Cummings et al., 2004; Salonen et al. 2009). Kwok, Ling, Leung, and Li (2013) concluded that father self-sufficiency and marriage satisfaction predicts significant fatherly involvement. Çelik and Bulut (2019) concluded that there is a strong correlation between the positive feelings of children towards their fathers and their perception of the quality of the relationship between the parents. Gazi (2019) concluded that marital harmony perceived by mothers predicts father involvement.

Another important finding of this study involves the effects of implicit and explicit messages conveyed by mothers to their children about their fathers. The participants indicated that messages conveyed by their mothers about their fathers were inconsistent, and that this could have caused them to develop ambivalent feelings towards their fathers. The participants could not differentiate between the concepts of "being a husband" and "being a father" when evaluating the phenomenon of fatherhood from the perspective of their mothers. They stated that the negative evaluations of their mothers about their husbands and the participants' own negative feelings towards their fathers were related to each other. Our findings also indicate that the participants received messages from their mothers about them tolerating their marriage only for the sake of their children and that they were making a sacrifice; these messages became a factor in making the participants feel guilty, and that in turn affected their father-child relationship negatively.

This result is significant as it clearly indicates that mothers are important actors in the father-child relationship. Krampe (2009) reported that the father-child relationship is very important, contrary to what had been previously argued, and that mothers can reinforce or erode the psychological presence of the father presence in their children's minds. National and international research findings emphasizing based upon a systemic and multi-dimensional evaluation of the father-child relationship report that mothers assume a facilitator or inhibitor (=maternal gatekeeping) role in the development of that relationship (Allen \& Hawkins, 1999; Makusha \& Richter, 2016; Puhman \& Pasley, 2013, 2017; Schoppe-Sullivan et al., 2008; Trinder, 2008; Tu et al., 2014). Gazi (2019) reported that there is a negative correlation between maternal gatekeeping and father involvement/the father-adolescent relationship, and that maternal gatekeeping predicted the father's involvement negatively. Similarly, Kurşun (2019) stated that one of the predictors of paternal involvement is maternal gatekeeping. Çelik and Bulut (2019) reported that there is a very strong correlation between maternal support perceived by the children and their feelings towards their father.

\section{Conclusion}

This study is important because it reveals both a rigid relationship existing in middle income Turkish families between fathers and their children and an enmeshed relationship between mothers and their children. The study shows that the father-child relationship formed under the influence of the generational hierarchy leads to less than desirable relationship dynamics and is characterized by emotional distance. The mother-child relationship embodies strong emotional bond and children had traces of their mother's inner being in their selves. These differing relationships formed between the participants and their parents made it difficult for the participants to differentiate from their parents, especially their mothers and establish an autonomous self and this compromised the familial dynamics.

The study also contributes to the field by revealing that a problematic emotional bond between the parents may have a negative effect on the father-child relationship. The participants associated their parents' marital relationships with the distribution of roles within the family, and they stated that role distribution within the family is determined by the generational hierarchy. The participants perceived an imbalance in this distribution, which made their mother a victim and their father guilty. The findings also demonstrate that since the parents show their negative 
emotions to each other openly while only rarely showing or not showing their positive affections towards each other, the participants evaluate their parents' marriage as negative (strong and guilty father, victimized and suffering mother). This situation influences them to develop negative feelings towards their fathers.

Another contribution of this study to the field is that it reveals the role of inconsistent messages conveyed by mothers to their children regarding fathers in the development of children's negative feelings towards their fathers. While other studies in the field evaluate the maternal role in the father-child relationship according to parents' evaluations of themselves and each other, this study presents the possible effects of mothers' influences on the father-child relationship from the viewpoint of the children. The findings contribute to the field in this respect. One of the most striking findings of this study is that the participants associated the concepts of "being a husband" and "being a father" and evaluated their fathers from the perspective of their mothers. This finding reveals the effects on their father-child relationship of the children's sympathy for and identification with their mothers.

The main significance of this study is that it indicates a need to rearrange the structural and interpersonal boundary relationships in the family to reduce or eliminate the effects of gender and generational hierarchy for the sake of more healthy parent-child bonds. Greater emotional closeness between children and their fathers will benefit the developmental needs of the children. More egalitarian parenting practices will reduce the negative effects of children defending their mothers against the fathers, which leads to less satisfying father-child relations and less than desirable emotional satisfaction for the children and autonomous self. Finally, the findings of this study can inform counsellors' evaluations of father-child and family relationships within the collectivist cultures.

\section{Limitations and Future Research}

This qualitative study was designed to investigate how the marital relationship of parents and messages sent by mothers to their children regarding fathers are reflected in father-child relationships. The size and homogeneity of the sample is commensurate with the requirements of an interpretative phenomenology study for the purpose of explaining the reactions of a certain group of people towards a specific situation. The findings are not intended to be generalized. This study represents a crucial step toward understanding the relationship of young individuals with their parents who did not have a prearranged marriage and are rated at medium SES. However, the study only reflects the experiences of the children. Studying the experiences of mothers, fathers, and children in a comparative way will enrich the interpretations of father-child and familial relationships and help to obtain a more complicated picture. Additionally, supporting this study with more quantitative findings will contribute further to the field. If future studies, institutes, and training institutions that organize family counseling and parenting training programs take these study findings into account, they can more ably assist both children and parents. Moreover, introducing lectures about parenting, beneficial familial relationships, and the optimal father-child relationship into the curriculum of universities will help to inform future generations.

\section{References}

AÇEV. (2017). The involved fatherhood and its determinants in Turkey: Executive summary. Retrieved from http://www.en.acev.org/wp-content/uploads/2018/01/1_involved-fatherhood-and-its-determinants-in- turkey.pdf

Allen, S. M., \& Hawkins, A. J. (1999). Maternal gatekeeping: Mothers' beliefs and behaviors that inhibit greater father involvement in family work. Journal of Marriage and the Family, 61(1), 199-212. https://doi.org/10.2307/353894

Amato, P. R. (1998). More than money? Men's contributions to their children's lives. In A. Booth and A. C. Crouter (Eds.), Men in families: When do they get involved? What difference does it make? (pp. 241-278). Mahwah, NJ: Lawrence Erlbaum Associates, Publishers.

Amato, P. R., \& Booth, A. (1997). A generation at risk: Growing up in an era of family upheaval. Cambridge, MA: Harvard University Press.

Ataca, B., Kağıtçıbaşı, Ç., \& Diri, A. (2005). Turkish family and the value of children: Trends over time. In G. Trommsdorff \& B. Nauck (Eds.), The value of children in cross-cultural perspective: Case studies from eight societies (pp. 91-119). Lengerich, Germany: Pabst.

Ataca, B. (2009). Turkish family structure and functioning. In S. Bekman \& A. Aksu- Koc (Eds.), Perspectives on human development, family and culture (pp. 108- 125). Cambridge, England: Cambridge University Press. https://doi.org/10.1017/CBO9780511720437.010 
Barutcu, A., \& Hıdır, N. (2016). Türkiye'de babalığın değişen rolleri: (Pro)feminist babalar [Changing roles of fathers in Turkey: (Pro)feminist fatherhood]. Feminist Eleştiri, 8(2), 27-45. https://doi.org/10.1501/Fe0001_0000000163

Boratav-Bolak, H., Fişek, G. O., \& Ziya, H. E. (2014). Unpacking masculinities in the context of social change: Internal complexities of the identities of married men in Turkey. Men and Masculinities, 17(3), 299-324. https://doi.org/10.1177/1097184X14539511

Boratav-Bolak, H., Fisek, G. O., \& Ziya, H. E. (2017). Erkekliğin Türkiye halleri [Turkish forms of masculinity]. Istanbul, Turkey: Bilgi University Press.

Bouchard, G., \& Lee, C. M. (2000). The marital context for father involvement with their preschool children: The role of partner support. Journal of Prevention \& Intervention in the Community, 20(1-2), 37-53. https://doi.org/10.1300/J005v20n01_04

Bozok, M. (2018). Ebeveynlik, erkeklik ve çalışma hayatı arasında Türkiye'de Babalık. Türkiye'de Babalığı anlamak Serisi II [Fatherhood in Turkey amongst parenting, masculinity, and working life: To understand the paternity series in Turkey II] Istanbul, Turkey: ACEV Press. Retrieved from https://acev.org/wp-content/uploads/2018/05/EbeveynlikErkeklikCalismaHayati.pdf

Bulanda, R. E. (2004). Paternal involvement with children: The influence of gender ideologies. Journal of Marriage and Family, 66(1), 40-45. https://doi.org/10.1111/j.0022-2455.2004.00003.x

Cabrera, N., Fitzgerald, H. E., Bradley, R. H., \& Roggman, L. (2007). Modeling the dynamics of paternal influences on children over the life course. Applied Developmental Science, 11(4), 185-189. https://doi.org/10.1080/10888690701762027

Coley, R. L., \& Morris, J. E. (2002). Comparing father and mother reports of father involvement among low- income minority families. Journal of Marriage and Family, 64(4), 982-997. https://doi.org/10.1111/j.1741-3737.2002.00982.x

Coltrane, S. (1995). The future of fatherhood: Social demographic and economic influences on men's family involvements. In W. Marsiglio (Ed.), Research on men and masculinities series, 7. Fatherhood: Contemporary theory, research, and social policy (p. 255-274). Thousand Oaks, CA: Sage. https://doi.org/10.4135/9781483327242.n13

Cowan, C. P., \& Cowan, P. A. (2000). When partners become parents: The big life change for couples. Mahwah, N.J: Lawrence Erlbaum Associates.

Creswell, J. W. (2009). Research design: Qualitative, quantitative, and mixed methods approaches (3rd ed.). Thousand Oaks, CA: Sage Publications, Inc.

Crouter, A. C., Bumpus, M. F., Head, M. R., \& McHale, S. M. (2001). Implications of overwork and overload for the quality of men's family relationships. Journal of Marriage and Family, 63(2), 404-416. https://doi.org/10.1111/j.1741-3737.2001.00404.x

Cummings, E. M., Goeke-Morey, M. C., \& Raymond, J. (2004). Fathers in family context: Effects of marital quality and marital conflict. In M. E. Lamb (Ed.), The role of the fathering child development (4th Ed.), pp. 196-221. New York: John Wiley \& Sons Inc

Çelik, H., \& Bulut, O. (2019). Examining Turkish adults' recalled experiences of their father's presence. Journal of Family Issues, 40(9), 1224-1251. https://doi.org/10.1177/0192513X19835879

Çelik, H. (2019). The mediator roles of mothers in father-child communications and family relationships. Eurasian Journal of Educational Research, 80(84), 135-158. https://doi.org/10.14689/ejer.2019.84.7

Dubowitz, H., Black, M. M., Cox, C. E., Kerr, M. A., Litrownik, A. J., Radhakrishna, A., English, D. J., Wood Schneider, M., \& Runyan, D. K. (2001). Father involvement and children's functioning at age 6 years: A multisite study. Child Maltreatment, 6(4), 300-309. https://doi.org/10.1177/1077559501006004003

Fişek, G. O. (2018). Ilişski icinde ben: Kültür, aile, bireyselleşme ve psikanalitik arayıslar ["I" into the relationship: Culture, family, individuation and psycho- analytic searches]. Istanbul, Turkey: Bilgi University Press.

Flouri, E., \& Buchanan, A. (2004). Early father's and mother's involvement and child's later educational outcomes. British Journal of Educational Psychology, 74(2), 141-153. https://doi.org/10.1348/000709904773839806

Flouri, E. (2005). Fathering and child outcomes. Chichester, West Sussex: John Wiley \& Sons. Ltd. 
https://doi.org/10.1002/9780470713228

Floyd, K., \& Morman, M. T. (2005). Fathers' and sons' reports of fathers' affectionate communication: Implications of a naïve theory of affection. Journal of Social and Personal Relationships, 22, 99-109. https://doi.org/10.1177/0265407505049323

Formoso, D., Gonzales, N. A., Barrera, M., Jr., \& Dumka, L. E. (2007). Interparental Relations, Maternal Employment, and Fathering in Mexican American Families. Journal of Marriage and Family, 69(1), 26-39. https://doi.org/10.1111/j.1741-3737.2006.00341.x

Gaertner, B. M., Spinrad, T., Eisenberg, N., \& Greving, K. A. (2007). Parental childrearing attitudes as correlates of father involvement during infancy. Journal of Marriage and Family, 69(4), 962-976. https://doi.org/10.1111/j.1741-3737.2007.00424.x

Gazi, T. (2019). Annelik bekçiliği ve evlilik uyumunun baba katılımı ve baba-ergen ilişsilerindeki rolünün incelenmesi [Unpublished master's thesis]. Maltepe University Graduate School of Social Sciences, Maltepe University, Istanbul

Grossman, F. K., Pollack, W. S., \& Golding, E. (1988). Fathers and children: Predicting the quality and quantity of fathering. Developmental Psychology, 24(1), 82-91. https://doi.org/10.1037/0012-1649.24.1.82

Howard, K. S., Lefever, J. E. B., Borkowski, J. G., \& Whitman, T. L. (2006). Fathers' influence in the lives of children with adolescent mothers. Journal of Family Psychology, 20(3), 468-476. https://doi.org/10.1037/0893-3200.20.3.468

Hu, Z. W. (2011). The social construction of sexuality-the interior and exterior of marriage. Modern Living and Liberal Education Conference, 4(1), 113-141

Jacobs, J. N., \& Kelley, M. L. (2006). Predictors of paternal involvement in childcare in dual-earner families with young children. Fathering: A Journal of Theory, Research, and Practice about Men as Fathers, 4(1), 23-47. https://doi.org/10.3149/fth.0401.23

Kağıtçıbaşı, Ç. (2010). Benlik, aile ve insan gelşsimi kültürelpsikoloji [Family, self, and human development across cultures: Theory and applications]. Istanbul, Turkey: Koç University Press.

Krampe, E. M., \& Fairweather, P. D. (1993). Father presence and family formation: A theoretical reformulation. Journal of Family Issues, 14(4), 572-591. https://doi.org/10.1177/019251393014004006

Krampe, E. M., \& Newton, R. R. (2006). The father presence questionnaire: A new measure of the subjective experience of being fathered. Fathering: A Journal of Theory, Research, and Practice about Men as Fathers, 4(2), 159-190. https://doi.org/10.3149/fth.0402.159

Krampe, E. M. (2009). When is the father really there? A conceptual reformulation of the father presence. Journal of Family Issues, 30, 875-892. https://doi.org/10.1177/0192513X08331008

Kurşun, G. (2019). Baba katılımı ve annelik bekçiliği davranışının algılanan baba kabul-reddi ile iliş̧isininin incelenmesi [Unpublished master's thesis]. Maltepe University Graduate School of Social Sciences, Maltepe University, Istanbul.

Kwok, S. Y. C. L., Ling, C. C. Y., Leung, C. L. K., \& Li, J. C. M. (2013). Fathering self-efficacy, marital satisfaction and father involvement in Hong Kong. Journal of Child and Family Studies, 22(8), 1051-1060. https://doi.org/10.1007/s10826-012-9666-1

Lamb, M. (2000). The history of research on father involvement: An overview. Marriage and Family Review, 29(2), 23-42. https://doi.org/10.1300/J002v29n02 03

Lamb, M. E. (2002). Infant-father attachments and their impact on child development. In C. S. Tamis-LeMonda \& N. Cabrera (Eds.), Handbook of father involvement (pp. 93-117). Mahwah, NJ: Lawrence Erlbaum.

Lamb, M. E. (2010). How do fathers influence children's development? Let me count the ways. In M. E. Lamb (Ed.), The role of the father in child development (5th ed., pp. 1-26). New Jersey: John Willey \& Sons.

Lamb, M. E., \& Oppenheim, D. (1989). Fatherhood and father-child relationships: Five years of research. In S. A. Cath, A. Gurwitt, \& L. Gunsberg (Eds.), Fathers and their families (pp. 11-26.). Hillsdale, NJ: The Analytic Press.

Lincoln, Y. S., \& Guba, E. G. (1985) Naturalistic inquiry. Newbury Park, CA: SAGE Publications Inc. https://doi.org/10.1016/0147-1767(85)90062-8 
Makusha, T., \& Richter, L. (2016). Gatekeeping and its impact on father involvement among black south africans in rural KwaZulu-Natal. Culture, Health \& Sexuality, $18(3), \quad 308-320$. https://doi.org/10.1080/13691058.2015.1083122

Milkie, M., \& Peltola, P. (1999). Playing all the roles: Gender and the work balancing act. Journal of Marriage and the Family, 61, 476-490. https://doi.org/10.2307/353763

Morman, M. T., \& Floyd, K. (2006). Good fathering: Father and son perceptions of what it means to be a good father. Fathering: A Journal of Theory, Research, and Practice about Men as Fathers, 4(2), 113-136. https://doi.org/10.3149/fth.0402.113

Orbuch, T. L., Thornton, A., \& Cancio, J. (2000). The impact of marital quality, divorce, and remarriage on the relationships between parents and their children. Marriage and Family Review, 29, 221-246. https://doi.org/10.1300/J002v29n04_01

Parman, T. (2004). Psikanalitik denemeler [Psychoanalytic essays]. Ankara Turkey: Baglam Press.

Paquette, D., \& Bigras, M. (2010). The risky situation: A procedure for assessing the father-child activation relationship. Early Child Development and Care, 180(1-2), 33-50. https://doi.org/10.1080/03004430903414687

Paquette, D., Bolte, C., Turcotte, G., Dubeau, D., \& Bouchard, C. (2000). A new typology of fathering: Defining and associated variables. Infant and Child Development, 9(4), 213-230. https://doi.org/10.1002/1522-7219(200012)9:4<213::AID-ICD233>3.0.CO;2-0

Pleck, J. H. (2010). Paternal involvement: Revised conceptualization and theoretical linkages with child outcomes. In M. E. Lamb (Ed.), The role of the father in child development (5th ed., p. 58-93). John Wiley \& Sons Inc.

Puhlman, D. J., \& Pasley, K. (2013). Rethinking maternal gatekeeping. Journal of Family Theory \& Review, 5(3), 176-193. https://doi.org/10.1111/jftr.12016

Rane, T. R., \& McBride, B. A. (2000). Identity theory as a guide to understanding fathers' involvement with their children. Journal of Family Issues, 21(3), 347-366. https://doi.org/10.1177/019251300021003004

Salonen, A. H., Kaunonen, M., Åstedt-Kurki, P., Järvenpää, A-L., Isoaho, H., \& Tarkka, M-T. (2009). Parenting selfefficacy after childbirth. Journal of Advanced Nursing, 65(11), 2324-2336. https://doi.org/10.1111/j.1365-2648.2009.05113.x

Saracho, O. N., \& Spodek, B. (2008). Fathers: The 'invisible' parents. Early Child Development and Care, 178(7-8), 821-836. https://doi.org/10.1080/03004430802352244

Schoppe-Sullivan, S. J., Brown, G. L., Cannon, E. A., Mangelsdorf, S. C., \& Sokolowski, M. S. (2008). Maternal gatekeeping, coparenting quality, and fathering behavior in families with infants. Journal of Family Psychology, 22(3), 389-398. https://doi.org/10.1037/0893-3200.22.3.389

Schwartz, S. J., \& Finley, G. E. (2006). Father involvement, nurturant fathering, and young adult psychosocial functioning: Differences among adoptive, adoptive stepfather, and non-adoptive stepfamilies. Journal of Family Issues, 27(5), 712-731. https://doi.org/10.1177/0192513X05284003

Smith, J. A., \& Osborn, M. (2003). Interpretative phenomenological analysis. In J. A. Smith (Ed.), Qualitative psychology: A practical guide to research methods (pp. 51-80). Thousand Oaks, CA, US: Sage Publications, Inc.

Seery, B. L., \& Crowley, M. S. (2000). Women's emotion work in the family: Relationship management and the process of building father-child relationships. Journal of Family Issues, 21(1), 100-127. https://doi.org/10.1177/019251300021001005

Stolz, H. E., Barber, B. K., \& Olsen, J. A. (2005). Toward disentangling fathering and mothering: An assessment of relative importance. Journal of Marriage and Family, 67(4), 1076-1092. https://doi.org/10.1111/j.1741-3737.2005.00195.x

Sunar, D. (2002). Change and continuity in the Turkish middle class family. In E. Ozdalga \& R. Liljestrom (Eds.), Autonomy and dependence in family: Turkey and Sweden in critical perspective (pp. 217-238). Istanbul, Turkey: Swedish Research Institute.

Sunar, D. (2009). Mothers' and fathers' child-rearing practices and self-esteem in three generations of urban Turkish families. In S. Bekman \& A. Aksu-Koc (Eds.), Perspectives on human development, family and culture (pp. 126-139). Cambridge, England: Cambridge University Press. https://doi.org/10.1017/CBO9780511720437.011 
Sunar, D., \& Fişek, G. (2005). Contemporary Turkish families. In U. Gielen \& J. Roopnarine (Eds.), Families in global perspective (pp. 169-183). Boston, MA: Allyn \& Bacon.

Thomas, J. E., \& Hildingsson, I. (2009). Who's bathing the baby? The division of domestic labour in Sweden. Journal of Family Studies, 15(2), 139-152. https://doi.org/10.5172/jfs.15.2.139

Trinder, L. (2008). Maternal gate closing and gate opening in post divorce families. Journal of Family Issues, 29(10), 1298-1324. https://doi.org/10.1177/0192513X08315362

Tu, Y. C., Chang, J. C., \& Kao, T. F. (2014). A study on the relationships between maternal gatekeeping and paternal involvement in Taiwan. Procedia-Social and Behavioral Sciences, 122, 319-328. https://doi.org/10.1016/j.sbspro.2014.01.1347

Vogel, C. A., Bradley, R. H., Raikes, H. H., Boliler, K., \& Shears, J. K. (2006). Relation between father connectedness and child outcomes. Parenting: Science and Practice, 6(2-3), 189-209. https://doi.org/10.1207/s15327922par0602\&3_4 